\title{
Effect of Mg/Al molar ratio on the basicity of Mg-Al mixed oxide derived from Mg-Al hydrotalcite
}

\author{
Said Arhzaf *, Mohammed Naciri Bennani, Sadik Abouarnadasse, Hamid Ziyat and Omar Qabaqous \\ Laboratoire «Chimie-Biologie Appliquées à l'environnement », Equipe de recherche « Matériaux et Catalyse \\ Appliqués », Université Moulay Ismail, Département de chimie, Faculté des Sciences, BP. 11201 Zitoune, \\ Meknès, Maroc
}

\begin{abstract}
The fundamental character of the $\mathrm{Mg}-\mathrm{Al}$ mixed oxide $\left(\mathrm{Mg}_{\mathrm{n}}(\mathrm{Al}) \mathrm{O}\right)$, derived from the $\mathrm{Mg}$ - $\mathrm{Al}$ hydrotalcite $\left(\mathrm{Mg}_{\mathrm{n}} \mathrm{Al}-\mathrm{CO}_{3}-\mathrm{HT}\right)$, where $\mathrm{n}$ corresponds to the $\mathrm{Mg} / \mathrm{Al}$ molar ratio (n: 2, 2.5, 3, 3.5 and 4), was studied by using the adsorption of phenol as a probe acid molecule. The hydrotalcite precursors were prepared by the coprecipitation method. Their derived mixed oxides were obtained by thermal treatment at $450^{\circ} \mathrm{C}$ in a flow of air. The resulting solids were characterized by X-ray fluorescence spectroscopy (XRF), X-ray diffraction (XRD), infrared spectroscopy (FTIR), thermogravimetric and differential thermal analysis (TG-DTA), nitrogen physisorption (BET) and phenol chemisorption. The phenol adsorption followed by UV-Visible spectrophotometry shows that the basicity increases with the $\mathrm{Mg} / \mathrm{Al}$ molar ratio, such that maximum quantity of phenol adsorbed $\left(\mathrm{Q}_{\mathrm{ads}}=0.54 \mathrm{mmol} / \mathrm{g}_{\text {cat }}\right)$ was obtained with the mixed oxide derived from the $\mathrm{Mg}$ - $\mathrm{Al}$ hydrotalcite of $\mathrm{Mg} / \mathrm{Al} \mathrm{molar}$ ratio equal to 3.5 .
\end{abstract}

Keywords: Layered double hydroxides; Hydrotalcite; mixed oxide; coprecipitation; basicity; adsorption.

\section{Introduction}

Layered double hydroxides (LDHs), also known as hydrotalcite-like compounds are anionic clays, of

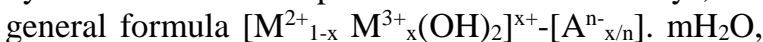
where the divalent metal ion $\mathrm{M}^{2+}$ maybe $\left(\mathrm{Mg}^{2+}, \mathrm{Zn}^{2+}\right.$, $\mathrm{Ni}^{2+}$, etc. $)$, and the trivalent metal ion $\mathrm{M}^{3+}\left(\mathrm{Al}^{3+}, \mathrm{Fe}^{3+}\right.$, $\mathrm{Ga}^{3+}$, etc. $)$. The compensating anions $\mathrm{A}^{\mathrm{n}-}$ maybe $\left(\mathrm{CO}_{3}{ }^{2}\right.$, $\mathrm{NO}_{3}{ }^{-}$, organic anions, etc) and $\mathrm{x}$ is equal to the $\mathrm{M}^{3+}$ / $\left(\mathrm{M}^{3+}+\mathrm{M}^{2+}\right)$ ratio, varying in the range of $0.2<\mathrm{x} \leq 0.33^{1-3}$. Their structure consists of brucitetype layers $\mathrm{Mg}(\mathrm{OH})_{2}$, where the substitution of $\mathrm{M}^{2+}$ by $\mathrm{M}^{3+}$ of relatively similar sizes $\left(\mathrm{r}_{\mathrm{M}^{2+}}-\mathrm{r}_{\mathrm{M}}^{3+}\right)<0,18 \AA$, results in a net positive charge of the layer, counterbalanced by anions, in the inter-sheets domain with water molecules ${ }^{2,4}$. Thus, the preparation of hydrotalcites with inorganic anions or organic anions has been described in the literature ${ }^{1-5}$.

Hydrotalcite-like Compounds have a wide field of application, as catalysts or catalyst supports, adsorbents for water treatment, ion exchangers, filters, stabilizers, and antacids in medicine.

The mixed $\mathrm{Mg}$-Al oxides derived from hydrotalcites are widely used in heterogeneous catalysis. Their catalytic properties depend on several parameters, such as the nature and the molar ratio of the metal cations, and the type of anions of the hydrotalcite inter-layer ${ }^{5-7}$. The thermal decomposition of hydrotalcites between 450 and $500^{\circ} \mathrm{C}$ affects the density of base sites ${ }^{8}$ and textural properties, giving rise to materials with high porosity and surface area with medium and high primary sites ${ }^{9}$. This paper deals with $\mathrm{LDHs}$ containing $\mathrm{Mg}^{2+}$ as divalent and $\mathrm{Al}^{3+}$ as trivalent cations, which corresponds to the natural minerals hydrotalcites. The calcination of these solids leads to the collapse of the structure and the formation of mixed oxides $\mathrm{Mg}_{\mathrm{n}}(\mathrm{Al}) \mathrm{O}$.

The main objective of this work is to measure the basicity of the mixed oxides $\mathrm{Mg}_{\mathrm{n}}(\mathrm{Al}) \mathrm{O}$, derived from their precursor hydrotalcite $\left(\mathrm{Mg}_{\mathrm{n}} \mathrm{Al}-\mathrm{CO}_{3}-\mathrm{HT}\right)$, by the phenol adsorption as a probe molecule, and examine the influence of the molar ratio $\mathrm{Mg} / \mathrm{Al}$ on the fundamental properties of these materials.

Moreover, in this article, the results of the study of the basicity of $\mathrm{Mg}-\mathrm{Al}$ mixed oxides derived from hydrotalcites by phenol adsorption were compared to those of the literature often using programmed temperature desorption of $\mathrm{CO}_{2}$ (TPD) ${ }^{8}$ or the titration with benzoic acid ${ }^{10}$ to understand the great difference in the basicity of these same solids studied by the two methods mentioned above.

\section{Experimental}

\subsection{Materials}

The salts of the metal cations used, magnesium nitrate 
$\mathrm{Mg}\left(\mathrm{NO}_{3}\right)_{2} \cdot 6 \mathrm{H}_{2} \mathrm{O}$ and aluminum nitrate $\mathrm{Al}\left(\mathrm{NO}_{3}\right)_{3} .9 \mathrm{H}_{2} \mathrm{O}$, are Merck products, with a purity greater than $99 \%$. Sodium hydroxide pellets $(\mathrm{NaOH}, \geq 98 \%)$ and sodium carbonate anhydrous powder $\left(\mathrm{Na}_{2} \mathrm{CO}_{3}, \geq 99 \%\right)$ were Fisher products. The solutions used in this study were prepared with deionized water.

\subsection{Sample preparation}

The $\mathrm{Mg}_{\mathrm{n}} \mathrm{Al}-\mathrm{CO}_{3}-\mathrm{HT}$ precursors with different $\mathrm{Mg} / \mathrm{Al}$ molar ratios (n: $2 ; 2.5 ; 3 ; 3.5$ and 4$)$ were prepared by the coprecipitation method at constant $\mathrm{pH}(10 \pm 0,2)$ under air, from an aqueous salt solution (1M) containing magnesium nitrate and aluminum nitrate, and a basic solution containing sodium hydroxide $1.5 \mathrm{M}$ and sodium carbonate $0.5 \mathrm{M}$.

Both solutions were mixed dropwise under agitation at $25^{\circ} \mathrm{C}$, and after the reactants were added, the slurry was aging for 24 hours at $65^{\circ} \mathrm{C}$. The precipitate obtained was filtered, washed several times in distilled water, dried in an oven at $80^{\circ} \mathrm{C}$ for 24 hours. The precursors were calcined to $450^{\circ} \mathrm{C}$ in a flow of air. The temperature was raised at a rate of $5^{\circ} \mathrm{C} / \mathrm{min}$ to reach $450^{\circ} \mathrm{C}$ and maintained for 8 hours. The generated mixed oxides obtained were denoted $\mathrm{Mg}_{\mathrm{n}}(\mathrm{Al}) \mathrm{O}$.

\subsection{Characterizations of the samples}

The chemical composition of the synthesized hydrotalcites was determined by X-ray fluorescence spectroscopy, to check whether the molar ratios of $\mathrm{Mg}^{2+} / \mathrm{Al}^{3+}$ are by the stoichiometry in the synthesis mixture. The samples were prepared by the pellet method (PROT-ELE03-v01) and then analyzed using the Axios type $\lambda$ dispersive $X$-ray fluorescence spectrophotometer.

Powder X-ray diffraction patterns of samples were recorded with a PW 1800 Philips automated goniometer (Bragg-Brentano) using monochromatized $\mathrm{Cu} \mathrm{K} \alpha$ radiation $(\lambda=1,5406 \AA, 40 \mathrm{kV}$, and $20 \mathrm{~mA})$. The angular $2 \theta$ diffraction range was between 5 and $70^{\circ}$.
The data were collected with an angular step of $0.04^{\circ}$ at 2 s per step.

Fourier transform infrared (FTIR) spectroscopy, was recorded by $\mathrm{KBr}$ pellet technique using a Shimadzu (JASCO 4100) instrument, in the wavelength range of $400-4000 \mathrm{~cm}^{-1}$ with a nominal resolution of $4 \mathrm{~cm}^{-1} . \mathrm{KBr}$ pellets were prepared by mixing very well dried of about 2 wt $\%$ hydrotalcite with 98 wt.\% $\mathrm{KBr}$ and pressing.

Thermogravimetric and differential thermal analysis (TG-DTA) were carried out in the air on a Shimadzu (TA-60). A few $\mathrm{mg}$ of samples were heated at $20^{\circ} \mathrm{C} / \mathrm{min}$ up $600^{\circ} \mathrm{C}$.

The surface area and pore volume measurements of the samples were carried out by nitrogen adsorption at $-196^{\circ} \mathrm{C}$ on a Micromeritics ASAP 2010 system using the BET method. The BJH method (Barrett-JoynerHalenda) applied to the desorption branch, was used to determine the size of the pores. Before the analysis, the samples were degassed in vacuum at $100^{\circ} \mathrm{C}$ for the $\mathrm{Mg}_{\mathrm{n}} \mathrm{Al}-\mathrm{CO}_{3}-\mathrm{HT}$ or at $250^{\circ} \mathrm{C}$ for mixed oxides $\left(\mathrm{Mg}_{\mathrm{n}}(\mathrm{Al}) \mathrm{O}\right)$.

The adsorption isotherms of phenol dissolved in cyclohexane at $25^{\circ} \mathrm{C}$ were used to estimate the density of base sites of the $\mathrm{Mg}_{\mathrm{n}} \mathrm{AlO}$-mixed oxide ${ }^{11}$. The amount of phenol adsorbed by the solids was measured by UV-Visible spectrometer (Shimadzu, UV-1240) at $\lambda=271 \mathrm{~nm}$.

\section{Results and discussion}

\subsection{Chemical analysis by $X$-ray fluorescence}

The chemical study by XRF of $\mathrm{Mg}_{\mathrm{X}} \mathrm{Al}-\mathrm{CO}_{3}-\mathrm{HT}$ showed that the $\mathrm{Mg} / \mathrm{Al}$ molar ratios found in solid samples are close to those in solution. This indicates that the operating conditions such as $\mathrm{pH}$, the choice of the precipitating agent, the crystallization temperature lead to the complete precipitation of aluminum and magnesium ions. Also, these chemical analyzes allow us to deduce the approximate formulas of the hydrotalcites studied (Table 1).

Table 1. Chemical composition and formulas of the samples studied.

\begin{tabular}{|c|c|c|c|c|c|}
\hline sample & $\begin{array}{c}\mathrm{Wt} \% \\
\mathrm{MgO}\end{array}$ & $\begin{array}{c}\mathrm{Wt} \% \\
\mathrm{Al}_{2} \mathrm{O}_{3}\end{array}$ & $\begin{array}{c}\mathrm{Mg} / \mathrm{Al} \\
\text { Molar ratio }\end{array}$ & ${ }^{(\mathrm{a})} \mathrm{x}$ & ${ }^{(\mathrm{b})}$ Formula $\left[\mathrm{Mg}_{1-\mathrm{x}} \mathrm{Al} \mathrm{x}_{\mathrm{x}}(\mathrm{OH})_{2}\right]^{\mathrm{x+}}\left[\mathrm{X}_{\left.\mathrm{x} / \mathrm{n} \cdot \mathrm{yH}_{2} \mathrm{O}\right]^{\mathrm{x}-}}\right.$ \\
\hline $\mathrm{Mg}_{2} \mathrm{Al}-\mathrm{CO}_{3}-\mathrm{HT}$ & 29.70 & 19.40 & 1.95 & 0,34 & {$\left[\mathrm{Mg}_{0,66} \mathrm{Al}_{0,34}(\mathrm{OH})_{2}\right]\left[\left(\mathrm{CO}_{3}\right)^{2-}{ }_{0,17} \cdot 0,49 \mathrm{H}_{2} \mathrm{O}\right]$} \\
\hline $\mathrm{Mg}_{2.5} \mathrm{Al}-\mathrm{CO}_{3}-\mathrm{HT}$ & 38.00 & 19.41 & 2.47 & 0,29 & {$\left[\mathrm{Mg}_{0,71} \mathrm{Al}_{0,29}(\mathrm{OH})_{2}\right]\left[\left(\mathrm{CO}_{3}\right)^{2-}{ }_{0,145} \cdot 0,565 \mathrm{H}_{2} \mathrm{O}\right]$} \\
\hline $\mathrm{Mg}_{3} \mathrm{Al}-\mathrm{CO}_{3}-\mathrm{HT}$ & 41.20 & 17.60 & 2.91 & 0,26 & {$\left[\mathrm{Mg}_{0,74} \mathrm{Al}_{0,26}(\mathrm{OH})_{2}\right]\left[\left(\mathrm{CO}_{3}\right)^{2-}{ }_{0,13} .0,61 \mathrm{H}_{2} \mathrm{O}\right]$} \\
\hline $\mathrm{Mg}_{3.5} \mathrm{Al}-\mathrm{CO}_{3}-\mathrm{HT}$ & 42.67 & 14.89 & 3.65 & 0,22 & {$\left[\mathrm{Mg}_{0,78} \mathrm{Al}_{0,22}(\mathrm{OH})_{2}\right]\left[\left(\mathrm{CO}_{3}\right)^{2-}{ }_{0,11} .0,67 \mathrm{H}_{2} \mathrm{O}\right]$} \\
\hline $\mathrm{Mg}_{4} \mathrm{Al}-\mathrm{CO}_{3}-\mathrm{HT}$ & 43.92 & 13.51 & 4.19 & 0,19 & {$\left[\mathrm{Mg}_{0,81} \mathrm{Al}_{0,19}(\mathrm{OH})_{2}\right]\left[\left(\mathrm{CO}_{3}\right)^{2-}{ }_{0,095} \cdot 0,72 \mathrm{H}_{2} \mathrm{O}\right]$} \\
\hline
\end{tabular}

\subsection{X-ray Diffraction}

The X-ray diffraction patterns of $\mathrm{Mg}_{\mathrm{n}} \mathrm{Al}-\mathrm{CO}_{3}-\mathrm{HT}$ (X: 2, 2.5, 3, and 3.5) are depicted in Figure 1A; the diffractograms of these materials present sharp and symmetric reflections of the (003), (006) planes at low values of $2 \Theta$ angles $\left(2 \Theta \approx 11-24^{\circ}\right)$, as well as other reflections at $2 \Theta \approx 34.5,38.8,45.9,60.5$, and $62^{\circ}$ respectively corresponding to the (009), (015), (018), (110) and (113) planes. These reflections are characteristic of a highly crystalline structure of hydrotalcites 2,8,12. The values of the unit cell parameters can be determined for the hexagonal cell using the $\mathrm{R} \overline{3} \mathrm{~m}$ space group in rhombohedral symmetry. 
The diffraction corresponding to the (003) plane was used to calculate the basal spacing between the layers, $\mathrm{c}=3 \mathrm{~d}_{003}$, while the (110) reflection was used to calculate the unit cell dimension, $a$, where $a=2 d_{110}{ }^{2}$.

The obtained values are in good agreement with those found in the literature ${ }^{13}$. The crystallite size of the samples was calculated from $\mathrm{X}$-ray line broadening, using the Scherrer equation $(\mathrm{L}=0.9 \lambda / \beta \cos \theta)^{14}$, considering the basal reflections (003) and (110) for the hydrotalcites, and (200) for the mixed oxides. The results of these calculations are summarized in Table 2.

In accord with previous measurements by Yun ${ }^{15}$ and Di Cosimo ${ }^{8}$, it is seen that the value of the lattice parameter increases with the $\mathrm{Mg}$ content indicating that the mean distance between cation-cation in the brucite layer increased by the substitution of smaller $\mathrm{Al}^{3+}$ radius ions by larger $\mathrm{Mg}^{2+}$ ions ${ }^{16,17}$.

A

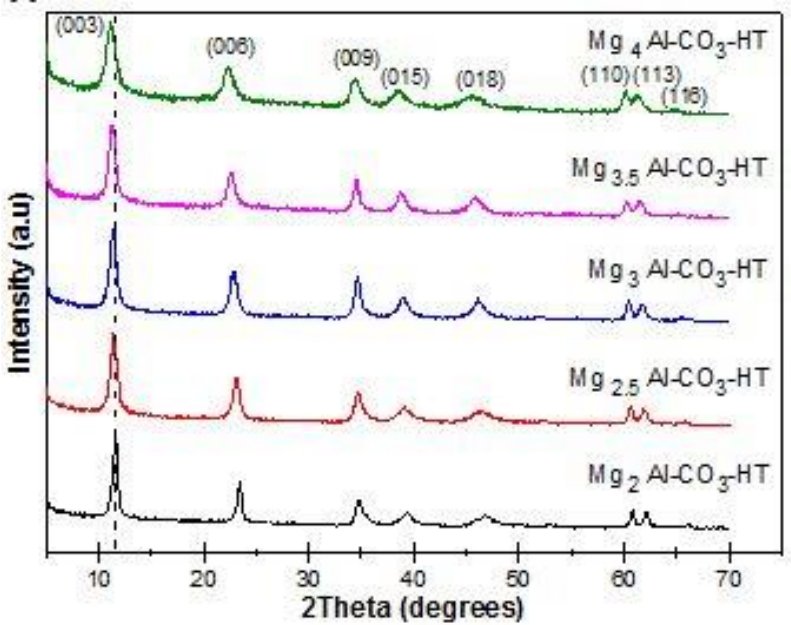

Simultaneously the increase of the c parameter with the increasing $\mathrm{Mg} / \mathrm{Al}$ molar ratio (i.e., with a decrease in the $\mathrm{Al}^{3+}$ cations) is coherent with the decreased attractive forces between the brucite-like layers with a positive charge and the interlayer anions.

After thermal decomposition of $\mathrm{MgAl}-\mathrm{CO}_{3}-\mathrm{HT}$ at $450^{\circ} \mathrm{C}$, the X-ray patterns of the calcined materials, shown in Figure 1B, present two new intensive diffractions lines at around 43,1 and $62.5^{\circ}$, which correspond to the (200) and (220) reflections of the $\mathrm{MgO}$ periclase-type structure ${ }^{8,17}$.

The average crystallite size of the mixed oxides is widely lower than the hydrotalcites. It decreases with an increase in the $\mathrm{Mg} / \mathrm{Al}$ molar ratio (exception for the molar ratio equal to 4 ). It is seen that the crystallite size of $\mathrm{Mg}_{3.5} \mathrm{Al}-\mathrm{O}(34 \AA)$ is slightly smaller than in the other mixed oxides (Table 2).

B

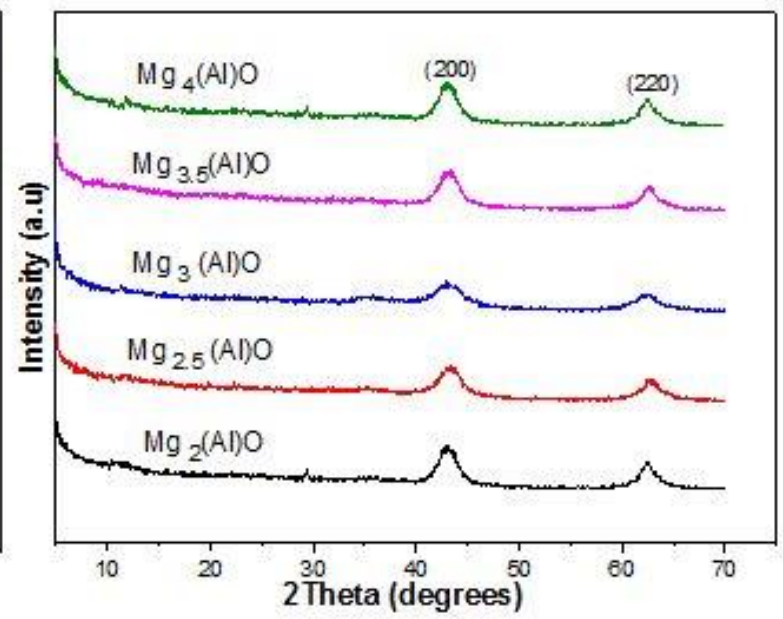

Figure 1. X-ray patterns of fresh (A) and calcined (B) materials

Table 2. Lattice parameters of hydrotalcites and crystallite size $(\mathbf{L}(\AA))$ of the samples.

\begin{tabular}{|c|c|c|c|c|c|c|c|}
\hline \multirow[t]{2}{*}{ Sample } & \multirow{2}{*}{$\begin{array}{l}\text { do03 } \\
(\AA)\end{array}$} & \multirow[t]{2}{*}{$c(\AA)$} & \multirow[t]{2}{*}{$\mathbf{d}_{110}(\AA)$} & \multirow[t]{2}{*}{$a(\AA)$} & \multicolumn{2}{|c|}{$\begin{array}{c}\text { The crystallites size of } \\
\text { hydrotalcites }\end{array}$} & \multirow{2}{*}{$\begin{array}{l}\text { The crystallites size of } \\
\text { mixed oxides } L_{(200)} \\
(\AA)\end{array}$} \\
\hline & & & & & $\mathbf{L}_{(003)}(\AA)$ & $\mathbf{L}_{(\mathbf{1 1 0})}(\AA)$ & \\
\hline $\mathrm{Mg}_{2} \mathrm{Al}-\mathrm{CO}_{3}-\mathrm{HT}$ & 7.59 & 22.75 & 1.52 & 3.037 & 92.8 & 151.7 & 48 \\
\hline $\mathrm{Mg}_{2.5} \mathrm{Al}-\mathrm{CO}_{3}-\mathrm{HT}$ & 7.70 & 23.08 & 1.53 & 3.048 & 93.8 & 150.8 & 42 \\
\hline $\mathrm{Mg}_{3} \mathrm{Al}-\mathrm{CO}_{3}-\mathrm{HT}$ & 7.80 & 23.44 & 1.53 & 3.059 & 96.7 & 147.8 & 37 \\
\hline $\mathrm{Mg}_{3,5} \mathrm{Al}-\mathrm{CO}_{3}-\mathrm{HT}$ & 7.84 & 23.45 & 1.54 & 3.068 & 97 & 147 & 34 \\
\hline $\mathrm{Mg}_{4} \mathrm{Al}-\mathrm{CO}_{3}-\mathrm{HT}$ & 7.89 & 23.47 & 1.54 & 3.069 & 99 & 150 & 50 \\
\hline
\end{tabular}

\subsection{Infrared spectroscopy (FTIR)}

Infrared spectroscopy has been widely used to characterize hydrotalcite and related materials $2,8,18$. The FT-IR spectra of $\mathrm{Mg}_{\mathrm{n}} \mathrm{Al}-\mathrm{CO}_{3}-\mathrm{HT}$ with $\mathrm{Mg} / \mathrm{Al}$ molar ratios from 2 to 4 are shown in Figure 2. In all cases, these spectra show the main active I.R vibrations in $\mathrm{Mg}_{\mathrm{n}} \mathrm{Al}-\mathrm{CO}_{3}-\mathrm{HT}$. An absorption band centered at $3460 \mathrm{~cm}^{-1}-3537 \mathrm{~cm}^{-1}$, is attributed to the hydroxyl groups. A slight shift towards higher frequencies is observed when the $\mathrm{Mg} / \mathrm{Al}$ molar ratio increases from 2 to 4 . This effect can be explained by the increase in $\mathrm{Mg}-\mathrm{OH}$ bond strength when the average load in the sheet increases by the decrease in the value of $\mathrm{d}_{003}$ observed by XRD ${ }^{1,19,20}$. The shoulder around $3050 \mathrm{~cm}^{-1}$ can be attributed to the $\mathrm{H}_{2} \mathrm{O}-\mathrm{CO}_{3}{ }^{2-}$ interlayer bridging mode by hydrogen bonds. The band around $1630 \mathrm{~cm}^{-1}$ is attributed to the deformation vibration due to interlayer water $\delta \mathrm{H}_{2} \mathrm{O}^{1,20}$. The sharp, intense vibration bands observed around $1370-1380 \mathrm{~cm}^{-1}$ were assigned to the asymmetric 
stretching of $\mathrm{CO}_{3}{ }^{2-}$ anions. This band is broad, which suggests the presence of nitrate ions from the starting salts, especially since the mode of vibration of $\mathrm{NO}_{3}^{-}$is largely overlapped by the mode of vibration of $\mathrm{CO}_{3}{ }^{2-21}$. The bands observed at lower wavenumber $\left(400<v<1000 \mathrm{~cm}^{-1}\right)$ are caused by metal-oxygen (M-O) stretching vibrations (close to $700 \mathrm{~cm}^{-1}$ ) and metal hydroxide $(\mathrm{M}-\mathrm{OH})$ vibrations (between 600 and $\left.400 \mathrm{~cm}^{-1}\right)^{22,23}$.

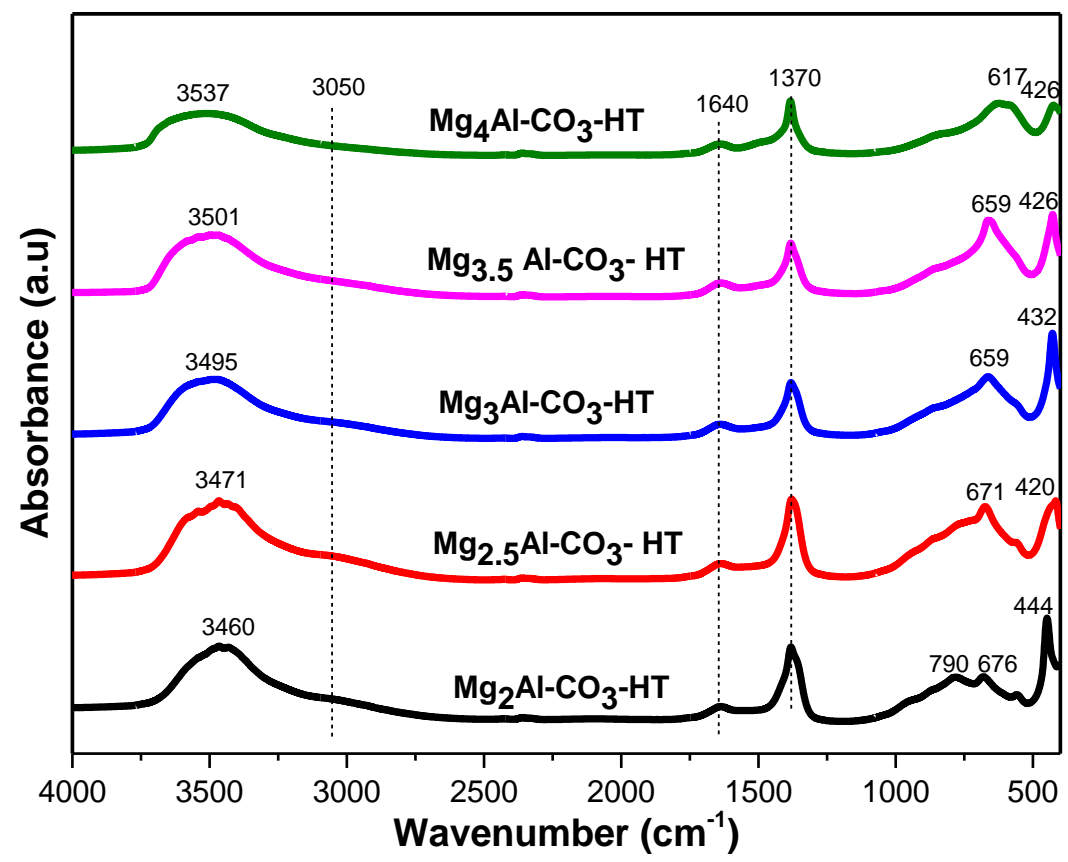

Figure 2. FTIR spectra of $\mathrm{Mg}_{\mathrm{n}} \mathrm{Al}-\mathrm{CO}_{3}-\mathrm{HT}(\mathrm{n}=\mathrm{Mg} / \mathrm{Al}=2 ; 2.5 ; 3 ; 3.5$ and 4)

\subsection{TG - DTA analysis}

Figure 3 shows the thermal decomposition of samples in the air by TG-DTA analysis in the range of temperature $25-600^{\circ} \mathrm{C}$. The decomposition profiles are in good agreement with those in the literature for

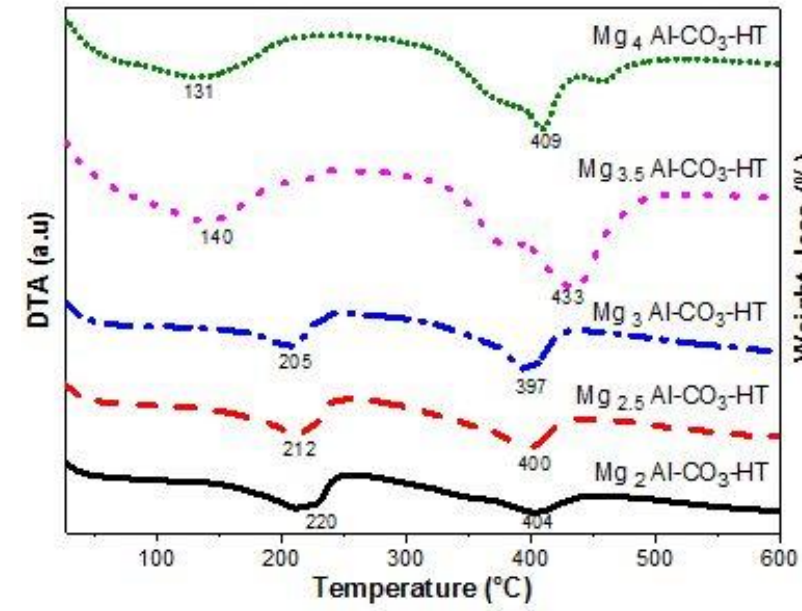

Figure 3. TG-DTA profiles of $\mathrm{Mg}_{\mathrm{n}} \mathrm{Al}-\mathrm{CO}_{3}-\mathrm{HT}(\mathrm{n}=\mathrm{Mg} / \mathrm{Al}=2 ; 2.5 ; 3 ; 3.5$ and 4) hydrotalcite-like compounds, with a total weight loss in the range of 35-46 wt\% ${ }^{24,25}$. The thermograms of all solids presented two weight loss regions, corresponding to endothermic events in the DTA analysis, as classically found for LDH materials ${ }^{26,27}$.

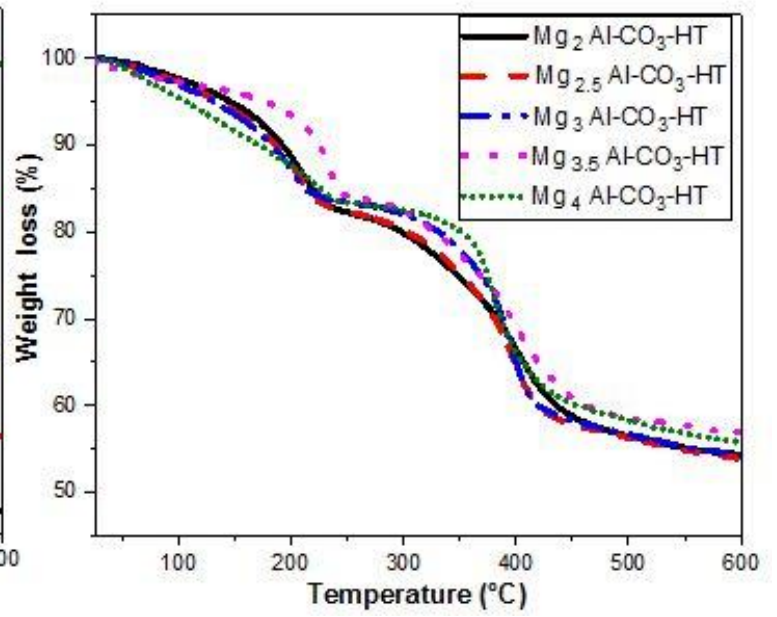

In our case, the shapes of the TGA curves and the positions of the DTA peaks show similarities between the synthesized materials; the differences only concern the total weight loss and the thermal stability of the samples.

The $\mathrm{Mg}_{3.5} \mathrm{Al}-\mathrm{CO}_{3}-\mathrm{HT}$ sample had the lowest weight loss of all the samples and showed high thermal stability since the second DTA peak is extended at a high temperature equal to $433^{\circ} \mathrm{C}$.
The first region at temperatures below $207^{\circ} \mathrm{C}$, corresponding to a weight loss of $11-18 \mathrm{wt} \%$, is related from weakly connected water molecules located in the interlayer domain or adsorbed on the outer surfaces of the crystals ${ }^{4}$. In contrast, the second peak at $\left(300-500^{\circ} \mathrm{C}\right)$ stems from the dehydroxylation of the brucite-like sheets and decomposition of the compensating anions in the interlayer ${ }^{28}$. 


\subsection{Adsorption of $\mathrm{N}_{2}$}

The values of the BET surface areas and porosities of $\mathrm{Mg}_{\mathrm{n}} \mathrm{Al}-\mathrm{CO}_{3}-\mathrm{HT}$ and mixed oxides $\mathrm{Mg}_{\mathrm{n}}(\mathrm{Al}) \mathrm{O}$ are presented in Table 3. All materials have an average pore size in the range of $9-21 \mathrm{~nm}$, suggesting that all the samples are mesoporous materials.

The surface areas and pore volumes for mixed oxides $\mathrm{Mg}_{\mathrm{n}}(\mathrm{Al}) \mathrm{O}$ are higher than those of their precursors $\mathrm{Mg}_{\mathrm{n}} \mathrm{Al}-\mathrm{CO}_{3}-\mathrm{HT}$ (Table 3), Indeed, during the calcination, the departure of water and carbonates leads to a considerable increase in the surface and volume of the pores. The mixed oxide with $\mathrm{Mg} / \mathrm{Al}$ ratio equal to 3.5 shows smaller crystallites size
$(\mathrm{L}=34 \AA)$, higher surface area $\left(214 \mathrm{~m}^{2} / \mathrm{g}\right)$, and higher pore volume $\left(0.80 \mathrm{~cm}^{3} / \mathrm{g}\right)$.

The adsorption-desorption isotherms of the mixed oxides, which is shown in Figure 4, corresponds to type IV ${ }^{29}$ according to IUPAC classification with a hysteresis loop characteristic of mesoporous materials ${ }^{8,30}$.

Moreover, the hysteresis loop begins at a high relative pressure, which further justifies the mesoporous nature of these materials. The type $\mathrm{H} 3$, according to the IUPAC classification, is observed for all the samples, which have non-rigid aggregates of platelet like particles forming slit-like pores ${ }^{31}$.

Table 3. Textural properties of the samples.

\begin{tabular}{|c|c|c|c|}
\hline Sample & S $_{\text {BET }}\left(\mathbf{m}^{2} / \mathbf{g}\right)$ & Pore diameter $(\mathbf{n m})$ & Pore volume $\left(\mathbf{c m}^{3} / \mathbf{g}\right)$ \\
\hline $\mathrm{Mg}_{2} \mathrm{Al}-\mathrm{CO}_{3}-\mathrm{HT}$ & 75 & 14 & 0.41 \\
\hline $\mathrm{Mg}_{2.5} \mathrm{Al}_{-}-\mathrm{CO}_{3}-\mathrm{HT}$ & 93 & 21 & 0.61 \\
\hline $\mathrm{Mg}_{3} \mathrm{Al}-\mathrm{CO}_{3}-\mathrm{HT}$ & 105 & 16 & 0.50 \\
\hline $\mathrm{Mg}_{3.5} \mathrm{Al}-\mathrm{CO}_{3}-\mathrm{HT}$ & 101 & 18 & 0.57 \\
\hline $\mathrm{Mg}_{4} \mathrm{Al}_{-}-\mathrm{CO}_{3}-\mathrm{HT}$ & 56 & 12 & 0.33 \\
\hline $\mathrm{Mg}_{2}(\mathrm{Al}) \mathrm{O}$ & 168 & 11 & 0.53 \\
\hline $\mathrm{Mg}_{2.5}(\mathrm{Al}) \mathrm{O}$ & 198 & 20 & 0.78 \\
\hline $\mathrm{Mg}_{3}(\mathrm{Al}) \mathrm{O}$ & 210 & 15 & 0.72 \\
\hline $\mathrm{Mg}_{3.5}(\mathrm{Al}) \mathrm{O}$ & 214 & 13 & 0.80 \\
\hline $\mathrm{Mg}_{4}(\mathrm{Al}) \mathrm{O}$ & 154 & 9 & 0.42 \\
\hline
\end{tabular}

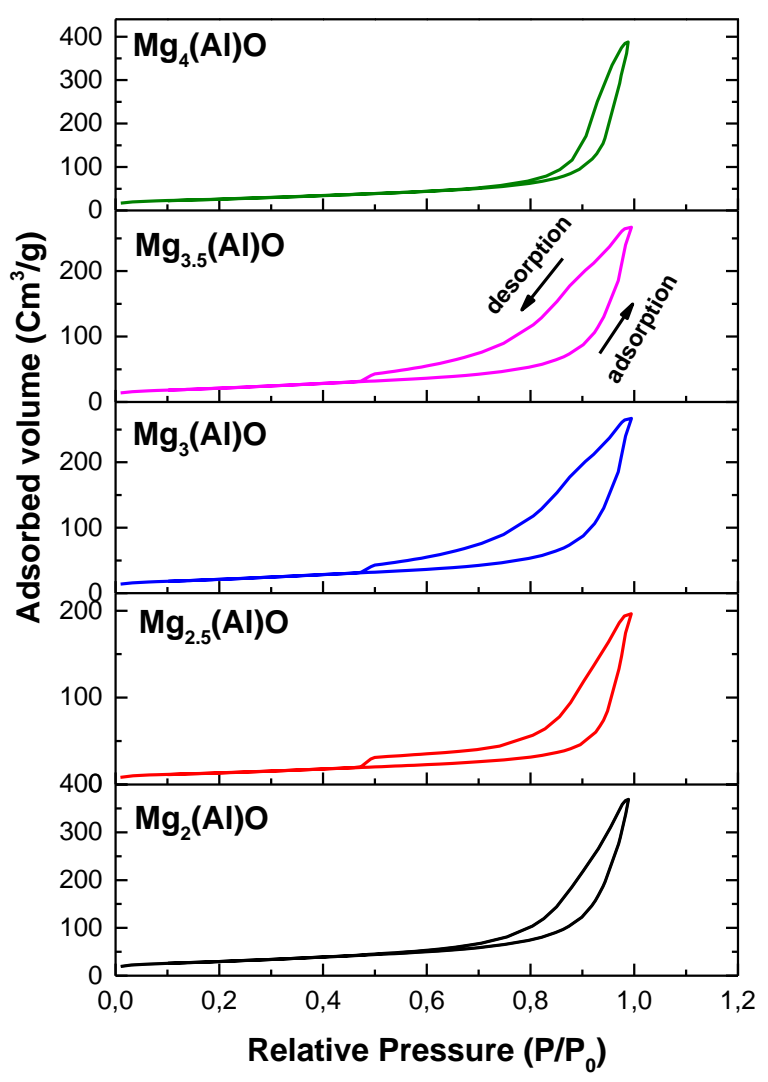

Figure 4. Nitrogen adsorption/desorption isotherms for $\mathrm{Mg}_{\mathrm{n}} \mathrm{Al}$-mixed oxides 


\subsection{Basic properties of the $\mathrm{Mg}$-Al mixed oxides 3.6.1. Phenol adsorption}

To probe the basic properties of mixed oxides, the adsorption of phenol $\left(\mathrm{pK}_{\mathrm{a}}=9.9\right)$ at $25^{\circ} \mathrm{C}$ was used. It has been reported to be an effective method to measure the strong basic sites of porous solids ${ }^{32,33}$.

Standard solutions of phenol in cyclohexane were prepared at room temperature. A quantity of $25 \mathrm{ml}$ for each standard solution was taken in separate conical flasks to which $50 \mathrm{mg}$ of solid was added, and each mixture was kept in a shaker for $3 \mathrm{~h}$. After equilibrium was reached, solids were separated from the solution by vacuum filtration. The concentration of phenol in the cyclohexane solvent after adsorption was evaluated by a Shimadzu, UV-1240 spectrometer $(\lambda=271 \mathrm{~nm})$. The phenol adsorption isotherms of all catalysts are presented in Figure 4. All five isotherms were of the Langmuir type, indicating chemisorption of phenol.

Figure 4 shows that all the samples can adsorb phenol, which means that they own basic surface sites, and
$\mathrm{Mg}_{3.5}(\mathrm{Al}) \mathrm{O}$ has the highest amount of strong basic sites. It was observed that the number of strong basic sites of the solids was increased with the $\mathrm{Mg} / \mathrm{Al}$ molar ratio and came up to the maximum value at the $\mathrm{Mg} / \mathrm{Al}$ molar ratio of 3.5. Numerous authors have shown that the basic properties of the surface of $\mathrm{MgAl}$-mixed oxides derived from $\mathrm{Mg}$-Al hydrotalcites depend on their composition; a straightforward correlation has been established between the composition and the basicity: when the amount of $\mathrm{Al}$ increases, the total number of basic sites decreases ${ }^{34,35}$.

However, the strength and the proportion of more robust sites are also changed; this may compensate for the decrease in total basicity. Indeed, lowering the $\mathrm{Mg} / \mathrm{Al}$ ratio results in the creation of stronger basic sites. In the case of $\mathrm{Mg}-\mathrm{Al}$ mixed oxides, the active basic sites are associated with hydroxide groups and different $\mathrm{Mg}^{2+}-\mathrm{O}^{2-}$ acid-base pairs. The basicity of the Lewis sites associated with $\mathrm{O}^{2-}$ anions depends on their coordination.

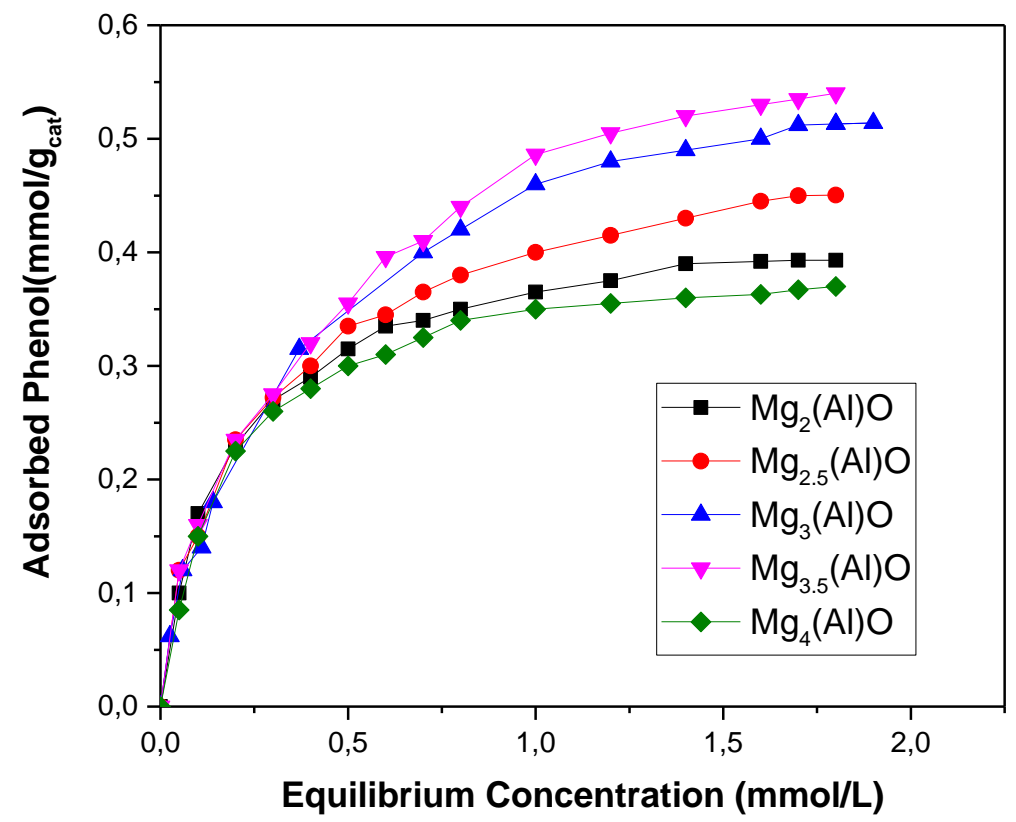

Figure 5. Phenol adsorption isotherms studies of $\mathrm{Mg}_{\mathrm{n}} \mathrm{Al}$-mixed oxides

\subsubsection{Effect of $\mathrm{Mg} / \mathrm{Al}$ molar ratio on amount} phenol adsorbed and on the BET specific surface The amount of phenol adsorbed at $25^{\circ} \mathrm{C}$ and the surface area on each mixed oxide, are plotted according to the $\mathrm{Mg} / \mathrm{Al}$ molar ratio in Figure 5. It can be seen that the quantity of phenol adsorbed, and the surface area of mixed-oxides increase in parallel with the increases $\mathrm{Mg} / \mathrm{Al}$ molar ratio, to obtain maximum values with $\mathrm{Mg} / \mathrm{Al}=3.5$, then decrease sharply towards the lower values for $\mathrm{Mg} / \mathrm{Al}=4$. Therefore, the results suggest that $\mathrm{Mg} / \mathrm{Al}$ molar ratio equal to 3.5 presents the highest amount of strong basic sites in the interval of the molar ratios studied. These results may agree with several authors who have evaluated the acid-base properties of $\mathrm{Mg}-\mathrm{Al}$ mixed oxides using other methods with other probe molecules. The effect of the $\mathrm{Al}$ content on the basicity of $\mathrm{Mg}-\mathrm{Al}$ mixed oxides was studied by Nakatsuka et al. 36 (for $1<\mathrm{Mg} / \mathrm{Al}<9$ ) and by Fishel et al. ${ }^{37}$ (for $3<\mathrm{Mg} / \mathrm{Al}<6$ ) and by Di Cosimo et al. ${ }^{8}$ (for $1<\mathrm{Mg} / \mathrm{Al}<5$ ). Nakatsuka et al. ${ }^{36}$ reported that the basic site density measured by titration with benzoic acid depends on the $\mathrm{Al}$ content, reaching a maximum for $\mathrm{Mg} / \mathrm{Al}$ of about 2.6. Fishel et al. ${ }^{37}$ and Di Cosimo et al. ${ }^{8}$ measured the number of basic sites by Temperature-programmed desorption of chemisorbed $\mathrm{CO}_{2}$. For Fishel et al., the basic site density increases for lower $\mathrm{Mg} / \mathrm{Al}$ values, reaching a maximum at $\mathrm{Mg} / \mathrm{Al}=3$. For Di Cosimo et al., in samples of $\mathrm{Mg} / \mathrm{Al}>4$ the basic site density is lower, but in samples of $1<\mathrm{Mg} / \mathrm{Al}<4$, a highly interacting $\mathrm{Mg}-\mathrm{Al}$ oxide phase is formed, to increase the basic site density. 
Table 4 summarizes specific results reported in the literature on the number of strong basic sites of the same mixed oxides measured by temperature- programmed desorption of $\mathrm{CO}_{2}$ and by titration with benzoic acid, with our results using the adsorption of phenol.

Table 4. Strong basic sites of $\mathrm{Mg}_{\mathrm{n}} \mathrm{Al}$-mixed oxides ( $\mathrm{mmol} / \mathrm{g}$ ).

\begin{tabular}{|c|c|c|c|c|c|}
\hline \multicolumn{3}{|c|}{$\mathrm{Mg} / \mathrm{Al}$} & \multirow{2}{*}{$\begin{array}{c}\text { Strong bascic sites } \\
\text { by TPD of } \mathrm{CO}_{2} \\
\text { Ref. }{ }^{8}\end{array}$} & \multirow{2}{*}{$\begin{array}{c}\text { Strong bascic sites by } \\
\text { titration } \\
\text { Ref. }{ }^{10 ~} \mathbf{b}\end{array}$} & \multirow{2}{*}{$\begin{array}{l}\text { Strong bascic sites by } \\
\text { phenol adsorption } \\
\text { This work }\end{array}$} \\
\hline Ref. ${ }^{8}$ & Ref. ${ }^{10}$ & This work & & & \\
\hline I & 2 & 1.95 & I & 0.45 & 0.39 \\
\hline I & 2.33 & 2.47 & I & 0.80 & 0.45 \\
\hline 3 & I & 2.91 & 0.064 & 1.35 & 0.51 \\
\hline I & 3.54 & 3.65 & I & 1.05 & 0.54 \\
\hline 4.5 & 4 & 4.19 & 0.039 & 0.90 & 0.37 \\
\hline
\end{tabular}

a: strong basic sites calculated from reference ${ }^{8}$

b: strong basic sites took directly from the results of the reference ${ }^{10}$

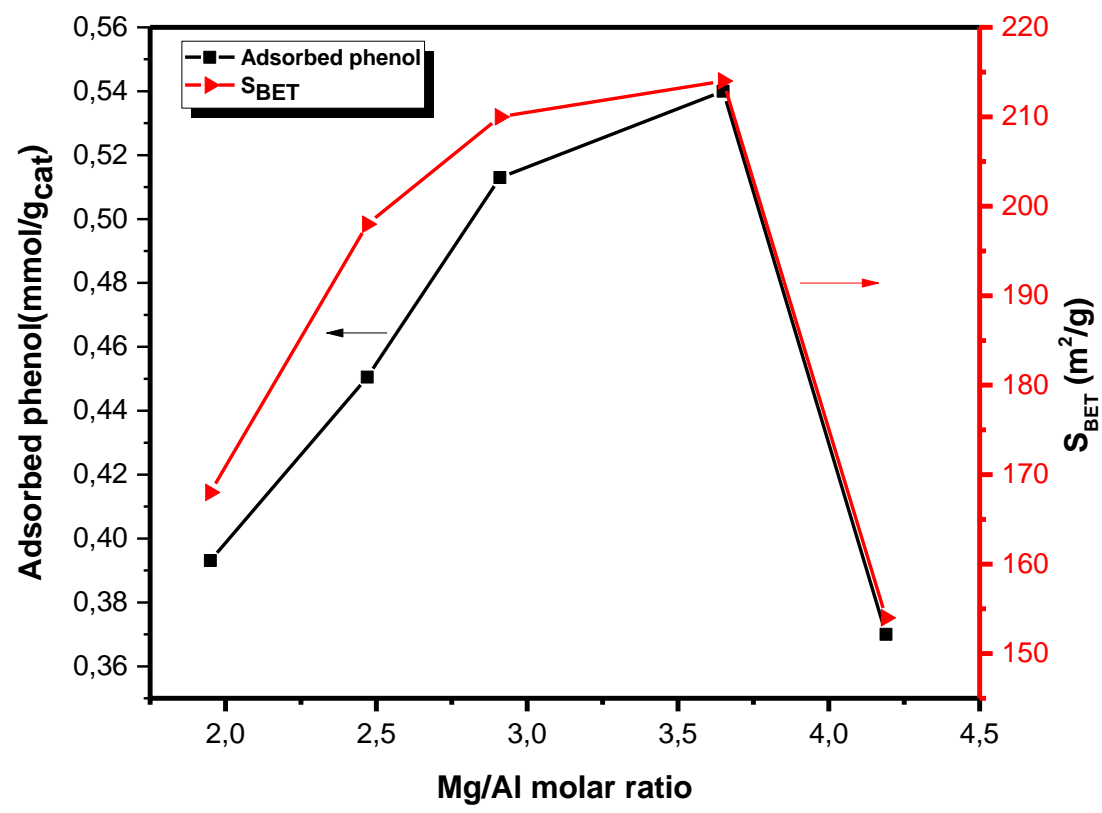

Figure 6. The relation between amount phenol adsorbed, surface area, and $\mathrm{Mg} / \mathrm{Al}$ molar ratio

\section{Conclusions}

$\mathrm{Mg}-\mathrm{Al}$ hydrotalcite-like materials at different $\mathrm{Mg} / \mathrm{Al}$ molar ratio, containing $\mathrm{CO}_{3}{ }^{2-}$ interlayer anions, were prepared by the coprecipitation method. The thermal treatment under air at $450^{\circ} \mathrm{C}$ of the synthesized materials, led to the decomposition of the hydrotalcite structure, and formation of $\mathrm{Mg}-\mathrm{Al}$ mixed oxides.

The basic properties of these mixed oxides have been evaluated by chemisorption of phenol as a probe molecule and compared with the results of the literature using other probe molecules, such as benzoic acid or carbon dioxide.

From the results obtained, it appears that:

- The composition of the synthesized materials has been confirmed by different physicochemical techniques (XRD, FTIR....).

- BET analysis has shown that these mixed oxides are mesoporous materials, and their specific surface area increases with the $\mathrm{Mg} / \mathrm{Al}$ molar ratio and come up to the maximum value at the $\mathrm{Mg} / \mathrm{Al}$ molar ratio of 3.5.

- The influence of the aluminum content on the basic properties showed that the basicity of these materials increases with the decrease in the amount of aluminum (i.e., with the increase in the $\mathrm{Mg} / \mathrm{Al}$ molar ratio, up to 3.5 ).

- The evaluation of the basicity by chemisorption of phenol showed that the number of basic sites varies in parallel with the $\mathrm{Mg} / \mathrm{Al}$ molar ratio and the specific surface of these materials.

- The disparity noted in the determination of the basicity of the solids with one of the three methods (TPD of $\mathrm{CO}_{2}$, titration with benzoic acid or absorption of phenol) perhaps due to the divergence of the technique itself, or to the non-reproducibility of sample preparation, conducting to solids with different basic properties. 


\section{Acknowledgments}

The authors would like to acknowledge the support and technical assistance of Interface Regional University Center (Moulay Ismail University, Meknes), CNRST-Rabat-Morocco, and we thank Professor Kamma Mohammed. He helped us to correct this article into the English language.

\section{References}

1- S. Miyata, The Syntheses of Hydrotalcite-Like Compounds and Their Structures and PhysicoChemical Properties-I: the Systems $\mathrm{Mg}^{2+}-\mathrm{Al}^{3+}-$ $\mathrm{NO}^{3-}, \mathrm{Mg}^{2+}-\mathrm{Al}^{3+}-\mathrm{Cl}^{-}, \mathrm{Mg}^{2+}-\mathrm{Al}^{3+}-\mathrm{ClO}^{4-}, \mathrm{Ni}^{2+}-$ $\mathrm{Al}^{3+}-\mathrm{Cl}^{-}$and $\mathrm{Zn}^{2+}-\mathrm{Al}^{3+}-\mathrm{Cl}^{-}$, Clays Clay Miner, 1975, 23, 369-375.

2- F. Cavani, F. Trifiro, A. Vaccari, Hydrotalcitetype anionic clays: Preparation, properties and applications, Catal today, 1991, 11, 173-301.

3- A. Trave, A. Selloni, A. Goursot, D. Tichit, J. Weber, First-principles study of the structure and chemistry of $\mathrm{Mg}$-based hydrotalcite-like anionic clays, J Phys Chem B, 2002, 106, 12291-12296.

4- A. De Roy, C. Forano, K. El Malki, J.-P. Besse, Anionic clays: trends in pillaring chemistry, Expanded Clays and other microporous solids, Springer, 1992, 108-169.

5- P. Kuśtrowski, L. Chmielarz, E. Bożek, M. Sawalha, F. Roessner, Acidity and basicity of hydrotalcite derived mixed $\mathrm{Mg}$-Al oxides studied by test reaction of $\mathrm{MBOH}$ conversion and temperature-programmed desorption of $\mathrm{NH}_{3}$ and $\mathrm{CO}_{2}$, Mater Res Bull, 2004, 39, 263-281.

6- D. Tichit, M. H. Lhouty, A. Guida, B. H. Chiche, F. Figueras, A. Auroux, D. Bartalini, E. Garrone, Textural properties and catalytic activity of hydrotalcites, J Catal, 1995, 151, 50-59.

7- O. D. Pavel, D. Tichit, I.-C. Marcu, Acido-basic and catalytic properties of transition-metal containing $\mathrm{Mg}-\mathrm{Al}$ hydrotalcites and their corresponding mixed oxides, Appl Clay Sci, 2012, 61, 52-58.

8- J. I. Di Cosimo, V. K. Diez, M. Xu, E. Iglesia, C. R. Apesteguia, Structure and surface and catalytic properties of $\mathrm{Mg}$-Al basic oxides, J Catal, 1998, 178, 499-510.

9- M. Di Serio, M. Ledda, M. Cozzolino, G. Minutillo, R. Tesser, E. Santacesaria, Transesterification of soybean oil to biodiesel by using heterogeneous basic catalysts, Ind Eng Chem Res, 2006, 45, 3009-3014.

10-W. Xie, H. Peng, L. Chen, Calcined Mg-Al hydrotalcites as solid base catalysts for methanolysis of soybean oil, J Mol Catal A Chem, 2006, 246, 24-32.

11-Y. Xi, R. J. Davis, Influence of textural properties and trace water on the reactivity and deactivation of reconstructed layered hydroxide catalysts for transesterification of tributyrin with methanol, J Catal, 2009, 268, 307-317.
12-M. J. Climent, A. Corma, S. Iborra, K. Epping, A. Velty, Increasing the basicity and catalytic activity of hydrotalcites by different synthesis procedures, J Catal, 2004, 225, 316-326.

13-J. Pérez-Ramírez, A. Ribera, F. Kapteijn, E. Coronado, C. J. Gómez-García, Magnetic properties of $\mathrm{Co}-\mathrm{Al}, \mathrm{Ni}-\mathrm{Al}$, and $\mathrm{Mg}-\mathrm{Al}$ hydrotalcites and the oxides formed upon their thermal decomposition, J Mater Chem, 2002, 12, 2370-2375.

14-U. Holzwarth, N. Gibson, The Scherrer equation versus the debye-Scherrer equation', Nat Nanotechnol, 2011, 6, 534.

15-S. K. Yun, T. J. Pinnavaia, Water content and particle texture of synthetic hydrotalcite-like layered double hydroxides, Chem Mater, 1995, 7 , 348-354.

16-K. K. Rao, M. Gravelle, J. S. Valente, F. Figueras, Activation of $\mathrm{Mg}-\mathrm{Al}$ hydrotalcite catalysts for aldol condensation reactions, $J$ Catal, 1998, 173, 115-121.

17-P. Kuśtrowski, D. Sułkowska, L. Chmielarz, A. Rafalska-Łasocha, B. Dudek, R. Dziembaj, Influence of thermal treatment conditions on the activity of hydrotalcite-derived $\mathrm{Mg}$-Al oxides in the aldol condensation of acetone, Microporous Mesoporous Mater, 2005, 78, 11-22.

18-S. Abelló, F. Medina, D. Tichit, J. PérezRamírez, J. C. Groen, J. E. Sueiras, P. Salagre, Y. Cesteros, Aldol condensations over reconstructed $\mathrm{Mg}$-Al hydrotalcites: structureactivity relationships related to the rehydration method, Chem Eur J, 2005, 11, 728-739.

19-S. K. Sharma, P. K. Kushwaha, V. K. Srivastava, S. D. Bhatt, R. V Jasra, Effect of hydrothermal conditions on structural and textural properties of synthetic hydrotalcites of varying $\mathrm{Mg} / \mathrm{Al}$ ratio, Ind Eng Chem Res, 2007, 46, 4856-4865.

20-D. L. Bish, G. W. Brindley, A reinvestigation of takovite, a nickel aluminum hydroxy-carbonate of the pyroaurite group, Am Mineral, 1977, 62, 458-464.

21-J. T. Kloprogge, D. Wharton, L. Hickey, R. L. Frost, Infrared and Raman study of interlayer anions $\mathrm{CO}_{3}{ }^{2-}, \mathrm{NO}_{3}{ }^{-}, \mathrm{SO}_{4}{ }^{2-}$ and $\mathrm{ClO}^{4-}$ in $\mathrm{Mg} / \mathrm{Al}-$ hydrotalcite, Am Mineral, 2002, 87, 623-629.

22-M. K. Titulaer, J. B. H. Jansen, J. W. Geus, The quantity of reduced nickel in synthetic takovite: effects of preparation conditions and calcination temperature, Clays Clay Miner, 1994, 42, 249-258.

23-M. Del Arco, P. Malet, R. Trujillano, V. Rives, Synthesis and characterization of hydrotalcites containing $\mathrm{Ni}$ (II) and Fe (III) and their calcination products, Chem Mater, 1999, 11, 624-633.

24- A. Morato, C. Alonso, F. Medina, Y. Cesteros, P. Salagre, J. E. Sueiras, D. Tichit, B. Coq, Palladium hydrotalcites as precursors for the catalytic hydroconversion of $\mathrm{CCl} 2 \mathrm{~F} 2$ (CFC-12) and $\mathrm{CHClF}_{2}$ (HCFC-22), Appl Catal B Environ, 2001, 32, 167-179. 
25-F. Prinetto, G. Ghiotti, P. Graffin, D. Tichit, Synthesis and characterization of sol-gel Mg/Al and $\mathrm{Ni} / \mathrm{Al}$ layered double hydroxides and comparison with co-precipitated samples, Microporous Mesoporous Mater, 2000, 39, 229-247.

26-W. T. Reichle, S. Y. Kang, D. S. Everhardt, The nature of the thermal decomposition of a catalytically active anionic clay mineral, J Catal, 1986, 101, 352-359.

27-T. Hibino, Y. Yamashita, K. Kosuge,

A. Tsunashima, Decarbonation behavior of $\mathrm{Mg}$ $\mathrm{Al}-\mathrm{CO}_{3}$ hydrotalcite-like compounds during heat treatment, Clays Clay Miner, 1995, 43, 427-432.

28-R. L. Frost, W. N. Martens, K. L. Erickson, Thermal decomposition of the hydrotalcite: Thermogravimetric analysis and hot stage Raman spectroscopic study, J Therm Anal Calorim, 2005, 82, 603-608.

29-G. Leofanti, M. Padovan, G. Tozzola, B. Venturelli, Surface area and pore texture of catalysts, Catal today, 1998, 41, 207-219.

30-D. Brunauer, W. E. LSD, Deming, and Teller, J Am Chem Soc, 1940, 62, 1723.

31-M. Thommes, K. Kaneko, A. V Neimark, J. P. Olivier, F. Rodriguez-Reinoso, J. Rouquerol, K. S. W. Sing, Physisorption of gases, with special reference to the evaluation of the surface area and pore size distribution (IUPAC Technical
Report), Pure Appl Chem, 2015, 87, 1051-1069.

32-F. Li, X. Jiang, D. G. Evans, X. Duan, Structure and basicity of mesoporous materials from $\mathrm{Mg} / \mathrm{Al} / \mathrm{In}$ layered double hydroxides prepared by separate nucleation and aging steps method, J Porous Mater, 2005, 12, 55-63.

33-K. Parida, J. Das, Mg/Al hydrotalcites: preparation, characterization, and ketonization of acetic acid, J Mol Catal A Chem, 2000, 151, 185-192.

34- A. Corma, S. Iborra, S. Miquel, J. Primo, Catalysts for the production of fine chemicals: production of food emulsifiers, monoglycerides, by glycerolysis of fats with solid base catalysts, J Catal, 1998, 173, 315-321.

35-M. J. Climent, A. Corma, S. Iborra, J. Primo, Base catalysis for fine chemicals production: Claisen-Schmidt condensation on zeolites and hydrotalcites for the production of chalcones and flavanones of pharmaceutical interest, J Catal, 1995, 151, 60-66.

36-T. Nakatsuka, H. Kawasaki, S. Yamashita, S. Kohjiya, The Polymerization of $\beta$ propiolactone by calcined synthetic hydrotalcite, Bull Chem Soc Jpn, 1979, 52, 2449-2450.

37-C. T. Fishel, R. J. Davis, Characterization of magnesium-aluminum mixed oxides by a temperature-programmed reaction of 2-propanol, Langmuir, 1994, 10, 159-165. 